University of Nebraska - Lincoln

DigitalCommons@University of Nebraska - Lincoln

\title{
Remote Sensing of Cropland Agriculture
}

M. Duane Nellis

Kansas State University, duane.nellis@ttu.edu

Kevin P. Price

University of Kansas, kpprice@ksu.edu

Donald Rundquist

University of Nebraska-Lincoln, drundquist1@unl.edu

Follow this and additional works at: https://digitalcommons.unl.edu/natrespapers

Part of the Natural Resources and Conservation Commons

Nellis, M. Duane; Price, Kevin P.; and Rundquist, Donald, "Remote Sensing of Cropland Agriculture" (2009). Papers in Natural Resources. 217.

https://digitalcommons.unl.edu/natrespapers/217

This Article is brought to you for free and open access by the Natural Resources, School of at DigitalCommons@University of Nebraska - Lincoln. It has been accepted for inclusion in Papers in Natural Resources by an authorized administrator of DigitalCommons@University of Nebraska - Lincoln. 
Published in:

The SAGE Handbook of Remote Sensing. 2009. SAGE Publications. 14 Apr. 2010. <http://www.sage-ereference.com/hdbk_remotesense/Article_n26.html>. Chapter DOI: 10.4135/978-1-8570-2105-9.n26

\title{
Remote Sensing of Cropland Agriculture
}

\author{
M. Duane Nellis, Kevin P. Price, and Donald Rundquist
}

\begin{abstract}
M. Duane Nellis is Provost and Senior Vice President, as well as Professor of Geography, at Kansas State University. He has published over 100 articles and more than a dozen books and book chapters on various aspects of remote sensing and GIS applications to natural resources assessment, and other dimensions of rural geography. He is past president of both the Association of American Geographers (AAG), and the National Council for Geographic Education (NCGE). Nellis has also served as co-editor of the GIS/remote sensing journal Geocarto International. He has received numerous honors and awards including National Honors from the AAG, election as a fellow of the American Association for the Advancement of Science (AAAS), the Royal Geographical Society, and the Explorers Club. In addition, he is past Chair of theAAG Remote Sensing Specialty Group and received that groups, Outstanding Contributions Award. At Kansas State he received the University Outstanding TeachingAward, the Phi Kappa Phi Research ScholarsAward, and the University OutstandingAdvisorAward. Nellis completed his undergraduate degree at Montana State University and his masters and Ph.D. at Oregon State University. He started his academic career at Kansas State University, where he moved from Assistant to Full Professor, and where he served as the head of Geography Department andAssociate Dean of Arts and Sciences. In 1997, he was named Dean of the Eberly College of Arts and Sciences at West Virginia University. In 2004 he returned to Kansas State University, where he served as Provost and Senior Vice President. He was appointed President of the University of Idaho in 2009.
\end{abstract}

Kevin P. Price is a Professor of Geography and served as the Associate Director of the Kansas Applied Remote Sensing (KARS) Program for 15 years at the University of Kansas (KU). While at KU, he has also retained a courtesy appointment in the Environmental Studies Program. He recently accepted a new position at Kansas State University (KSU), and will have a joint appointment in Agronomy and Geography from August of 2008. Given his agricultural academic training and interests, he looks forward to working at KSU, which is a well-respected agricultural school. He has been the recipient of national awards for service within the remote sensing community and served as the Associate Chair and Chair of the Remote Sensing Specialty Group of the Association of American Geographers. He also served on two National Research Council (NRC) committees that addressed issues of sustainable development in Africa and environmental satellite data utilization. His academic training includes a Ph.D. in geography (specialty in biogeography, remote sensing, and GIS) at the University of Utah, and B.S. and M.S. degrees in range science at Brigham Young University. Before coming to KU, he was an Assistant Professor in Geography at Utah State University where he also served as an Adjunct Professor in the Departments of Forestry, Range Science, Fisheries and Wildlife, and Landscape Architecture. Dr. Price's research has focused on the use of tools in the GISciences to study 'natural' and anthropogenically driven forcings that influences ecosystem (including agro-ecosystem) dynamics. He has conducted research throughout most regions of the world, and is the author or co-author of over 230 publications and an investigator on 75 research grants and contracts.

Donald Rundquist is a Professor with the School of Natural Resources, Institute of Agriculture and Natural Resources, University of Nebraska-Lincoln (UNL). He also serves as Director of the Center for Advanced Land Management Information Technologies (CALMIT). Rundquist holds a Ph.D. in geography from UNL (1977). He has been conducting research in and teaching courses on the subject of remote sensing since the early 1970s. His research involves high spectral and spatial resolution remote sensing of both cropland-vegetation canopies and surface waters, field techniques in support of remote-sensing campaigns, and airborne imaging spectrometry. 
Keywords: Crop classification, Crop condition, Crop yield, Crop biophysical characteristics, Crop water management, Crop-related soil characteristics, Precision agriculture, Crop phenology and Nitrogen management.

\section{HISTORY OF REMOTE SENSING IN AGRICULTURE}

Remote sensing has long been used in monitoring and analyzing agricultural activities. Well prior to the first coining of the term 'remote sensing' in 1958 by Eveyln Pruitt of the U.S. Office of Naval Research (Estes and Jensen 1998), scientists were using aerial photography to complete soil and crop surveys associated with agricultural areas in the United States and other parts of the world (Goodman 1959). Most of such work in the 1930s involved general crop inventoriesbythe U.S. Department of Agriculture and soil survey mapping as part of the work of the then U.S. Soil Conservation Service. With new developments in infrared photography during World War II, remote sensing techniques evolved that allowed for greater understanding of crop status, water management, and crop-soil condition.

Pioneering work on remote sensing in agriculture was done by Robert Colwell at the University of California in the 1950s, and during the 1960s new laboratories oriented to applications in agriculture, such as the one at Purdue (see Landgrebe 1986), were developed. Crop identification and their areal coverage were early objectives, and Bauer (1985) provides information about projects such as the Corn Blight Watch Experiment and the Crop Identification Technology Assessment for Remote Sensing (CITARS) program.

In the early 1970s, NASA began funding selected universities via its University Affairs Program in an effort to stimulate the use of remote-sensing technologies, and states where agriculture was an important aspect of the economy began applying remote sensing to that sector. Centers and laboratories, such as those at Purdue and Kansas, were early contributors to the evolution of remote-sensing science in agriculture, and the research was important in the ultimate selection of the spectral bands incorporated into future sensor systems.

Subsequent investigations have included many types of sensors, and remote sensing has been proven capable of providing the necessary reliable data on a timely basis for a fraction of the cost of traditional methods of information gathering.

The Large Area Crop Inventory Experiment (LACIE) was the first U.S. government sponsored program aimed at examining the feasibility of using remotely sensed, satellite data, specifically Landsat, to estimate wheat production over large geographic areas. The idea was proposed by the National Research Council in 1960, and with the 
1972 launch of the first of the Landsat sensor configuration, the possibility of estimating wheat yield over wide areas became a reality. The LACIE program was operated jointly under the aegis of NASA, NOAA, and USDA. During 1974-75, the emphasis of the work was on developing both spectral 'signatures' for wheat and the yield-estimation models for the Great Plains of the U.S. Subsequently, the activity was expanded to include Canada and the Soviet Union. The successes of LACIE led to a follow-on project in 1980 called Agriculture and Resources Inventory Surveys Through Aerospace Remote Sensing (AgRISTARS). The goal of this new program was to expand upon LACIE and include monitoring of other crops such as barley, corn, cotton, rice, soybeans, and wheat. An overview of these programs can be found in Rundquist and Samson (1983), Bauer (1985), and Pinter et al. (2003), while details of historical development in remote-sensing science and also agricultural applications are provided by Reeves (1975).

\section{REMOTE SENSING APPLICATIONS IN AGRICULTURE}

\section{Crop classification, condition and yield}

Remote sensing has played a significant role in crop classification, crop health and yield assessment. Since the earliest stages of crop classification with digital remote sensing data, numerous approaches based on applying supervised and unsupervised classification techniques have been used to map geographic distributions of crops and characterize cropping practices. Depending on geographic area, crop diversity, field size, crop phenology, and soil condition, different band ratios of multispectral data and classifications schemes have been applied. Nellis (1986), for example, used a maximum likelihood classification approach with Landsat data to map irrigated crop area in the U.S. High Plains. Price et al. (1997) further refined such approaches, using a multi-date Landsat Thematic Mapper (TM) dataset in southwest Kansas to map crop distribution and USDA Conservation Reserve Program (CRP) lands in an extensive irrigated area.

Hyperspectral remote sensing has also helped enhance more detailed analysis of crop classification. Thenkabail et al. (2004) performed rigorous analysis of hyperspectral sensors (from 400 to $2500 \mathrm{~nm}$ ) for crop classification based on data mining techniques consisting of principal components analysis, lambda-lambda models, stepwise Discriminant Analysis and derivative greenness vegetation indices. Through these analyses they established 22 optimal bands that best characterize the agricultural crops. By increasing the number of channels beyond 22 bands, accuracies only increased marginally up to 30 bands and became asymptotic beyond that number. In comparison to Landsat Enhanced The matic Mapper data and other broadband sensors, these hyperspectral approaches increased accuracy for crop classification from 9 to $43 \%$. 
Relative to crop condition, some remote sensing studies have focused on individual physical parameters of the crop system, such as nutrient stress or water availability as variables in analyzing crop health and yield. Other research has focused more on synoptic perspectives of regional crop condition using remote sensing indices. At the same time, some researchers (Seidl et al. 2004) have demonstrated that such approaches can be limited for crop yield and health monitoring given satellite over flight timing in the context of the crop calendar.

The normalized difference vegetation index (NDVI), vegetation condition index (VCI), leaf area index (LAI), General Yield Unified Reference Index (GYURI), and temperature crop index (TCI) are all examples of indices that have been used for mapping and monitoring drought and assessment of vegetation health and productivity (Doraiswamy et al. 2003, Ferencz et al. 2004, Prasad et al. 2006). Wang et al. (2005), for example, used satellite remote sensing of NDVI to provide characterizations of landscape level patterns of net primary productivity within the U.S. Great Plains, and Kogan et al. (2005) used vegetation indices from Advanced Very High Resolution Radiometer (AVHRR) data to model corn yield and early drought warning in China. Hadria et al. (2006) provides an example of developing leaf area indices from four satellite scenarios to estimate distribution of yield and irrigated wheat in semi-arid areas. Zhang et al. (2005) have also modified leaf area indices based on MODIS (MODerate resolution Imaging Spectrometer) using a climate-variability impact index (CVII) related to contributions to monthly anomalies in annual crop growth. Using MODIS the researchers were able to establish the relationship between CVII and LAI to accurately model regional crop forecasts.

In addition, to refine regional crop forecasting, researchers have modified standard NDVI approaches using crop yield masking. This technique involves restricting analysis to a subset region's pixels rather than using all the pixels in the scene. According to work by Kastens et al. (2005) yield correlation masking is shown to have comparable performance to cropland masking across eight major U.S. crop forecasting scenarios. Jensen (2007) provides further examples of the broad range of popular vegetation indices used in remote sensing of agricultural systems.

Recent research has documented radar as a tool for crop monitoring. Chen and Mcnairn (2006) used radar, for example, in rice monitoring within Asia. In their work, they found that backscatter increases significantly during short periods of vegetation growth, which can be used to differentiate rice fields from other land cover.

Recent commercial satellites with fine spatial resolution have also proven of value in mapping crop growth and yield. Yang et al. (2006) used QuickBird satellite imagery for mapping plant growth and yield patterns within grain sorghum fields as compared with airborne multispectral image data. The results suggest QuickBird data and airborne spectral data were equally useful. 
Although satellite remotely sensed data have historically been used for assessing specific crop stress parameters, such as indications of nitrogen stress (Reyniers and Vrindts 2006), more detailed insights regarding crop condition are being gained using hyperspectral remote sensing, thermal radiometers, and related devices. Such approaches have also contributed to effective uses of these data in precision agriculture (Yang et al. 2004). Hyper-spectral sensors and related techniques can also be used to estimate various other crop biophysical and biochemical parameters, such as leaf nitrogen content, leaf chlorophyll content, and associated factors related to soil moisture (Goel et al. 2003). Remote sensing of soil moisture will be elaborated on later in this chapter. Ye et al. (2006) used hyper-spectral images to predict tree crop yield in citrus groves, Vijaya-Kumar and colleagues (2005) used an infrared thermometer and spectral radiometer for screening germplasm and stress in castor beans, while Nicholas (2004) used visible, near infrared, and thermal sensors to assess crop conditions.

Vegetation stages of development (phenology) are influenced by a variety of factors such as available soil moisture, dateof planting, air temperature, day length, and soil condition. These factors therefore also influence plant conditions and their productivity. For example, corn crop yields can be negatively impacted if temperatures are too high at the time of pollination. For this reason, knowing the temperature at the time of corn pollination could help forecasters better predict corn yields.

McMaster (2004) has summarized the importance of phenology, asserting that, 'Understanding crop phenology is fundamental to crop management, where timing of management practices is increasingly based on stages of crop development. Simulating canopy development is also critical for crop growth models, whether to predict the appearance of sources and sinks, determining carbon assimilation and transpiration, partitioning carbohydrates and nutrients, or determining critical life cycle events such as anthesis and maturity.'

During the era during which Landsat was temporarily privatized (see also Goward et al., in this volume) after the 1990s, some remote sensing scientists begin experimenting with the use of coarse spatial resolution $(1.0 \mathrm{~km}$ ) imagery (also see Justice et al., in this volume). These data were free, and they allowed for a synoptic view of the conterminous U.S. on a daily to bi-daily temporal frequency. As methods were developed for cloud removal or minimization, new high temporal (weekly to biweekly) cloud-free or near cloud-free datasets were made freely available for a variety of applications and research endeavors. In the early 1980s, Badhwar and Henderson (1981) published a paper in the Agronomy Journal describing the use of spectral data for characterizing terrestrial vegetation development. In 1990, Lloyd described the use of a shortwave vegetation index (the Normalized Difference Vegetation Index (NDVI)) for characterizing phenological stages of plant development for terrestrial land cover, and in 1994, Reed et al. described how high temporal resolution NDVI datasets could be used to examine variability in interannual phenology at the continental scale. 
Using coarse spatial resolution and high temporal resolution data, for the first time plant response to varying growing conditions could be examined at or near a continental scale, for example, the conterminous US. Since the publication of the manuscripts referenced above, many studies that followed used AVHRR NDVI datasets for such tasks as assessing crop relative condition and making yield forecasts (Steven et al. 1983, Quarmby et al. 1993, Groten 1993, Kastens et al. 2005), characterization of Central Great Plains grass life forms (Reed et al. 1996, Tieszen et al. 1997), studying vegetation response to intra- and interannual climatic variation (Yu et al. 2003, Breshears et al. 2005), and for many other agriculturally related purposes.

Annual NDVI profiles are extracted in operational remote sensing for 12 vegetation phenology metrics (VPMs), and these metrics are used to characterize agricultural vegetation response to varying climatic and land management practices (Reed et al. 1994; Figure 26.1 and Table 26.1).

\section{Crop biophysical characterization}

Remote sensing can play an important role in agriculture by providing timely spectralreflectance information that can be linked to biophysical indicators of plant health. Quantitative techniques can be applied to the spectral data, whether acquired from close-range or by aircraft or satellite-based sensors, in order to estimate crop status/condition. The technology is capable of playing an important role in crop management by providing at least the following types of information:

1. fraction of vegetative cover,

2. chlorophyll content,

3. green leaf area index, and,

4. other measurable biophysical parameters 


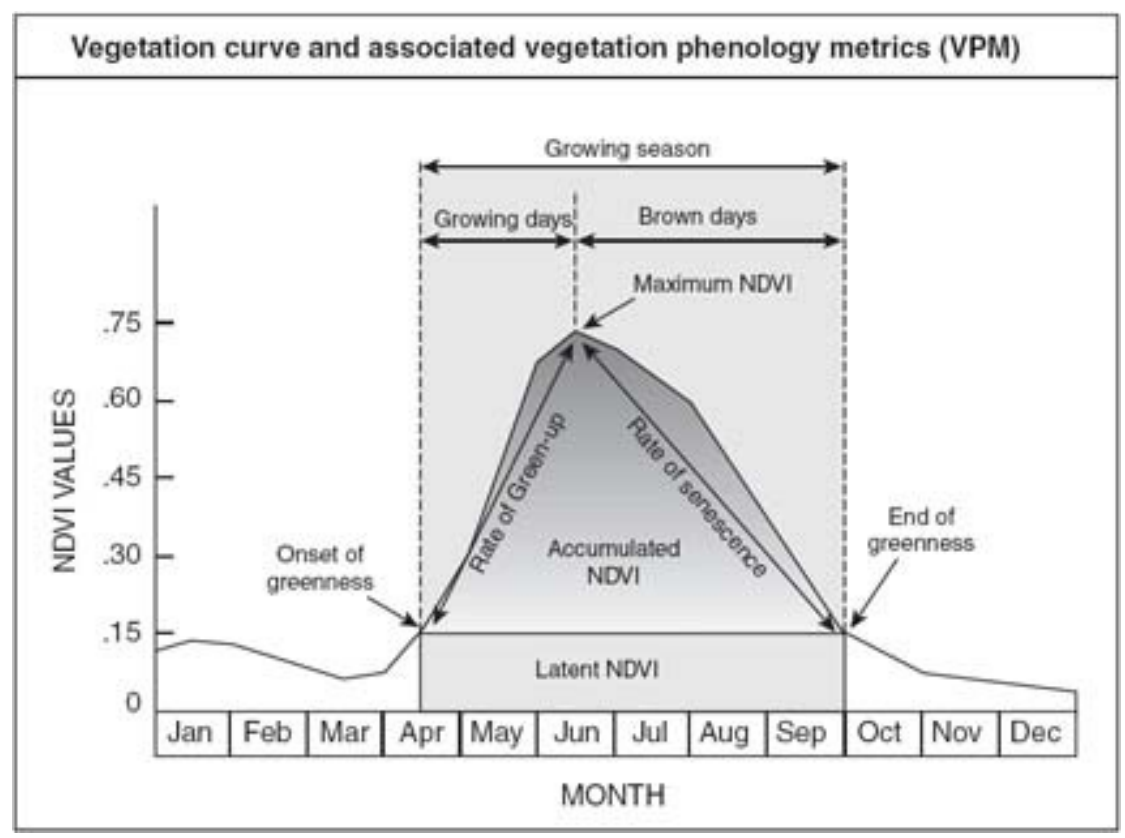

Figure 26.1 A twelve month, hypothetical NDVI temporal response curve for vegetation. Additionally, the vegetation metrics are displayed to show their relation to both NDVI values and time (after Reed et al. 1994).

Table 26.1 Vegetation phenology metrics characterize vegetation phenology and are used to develop summary regional data for research on agro-ecosystem attributes (after Reed et al. 1994)

\begin{tabular}{lll}
\hline Type & Metric & Interpretation \\
\hline Temporal & 1 Time of onset of greenness & Beginning of photosynthetic activity \\
& 2 Time of end of greenness & End of photosynthetic activity \\
& Luration of greenness & Length of photosynthetic activity \\
& Time of maximum greenness & Time when photosynthesis at maximum \\
NDVI-value & 5 Value of onset of greenness & Level of photosynthesis at start \\
& 7 Value of end of greenness & Level of photosynthesis at end \\
& 8 Range of NDVI & Level of photosynthesis at maximum \\
& 9 Accumulated NDVI & Range of measurable photosynthesis \\
Derived & 10 Rate of green-up & Net Primary Production (NPP) \\
11 Rate of senescence & Acceleration of increasing photosynthetic activity \\
12 Mean daily NDVI & Acceleration of decreasing photosynthetic activity \\
\hline
\end{tabular}

\section{Fraction of Vegetation Cover}

Remote sensing offers, bymeans of multitemporal data collection, the capability of monitoring changes in fraction of vegetative cover associated with crop phenology. Details associated with the growth of a corn crop over time were provided by Vina et al. 
(2004) who used visible atmospherically resistant spectral indices to document a capability for detecting changes in the crop due to biomass accumulation, changes induced by the appearance and development of reproductive structures, and the onset of senescence. Gitelson et al. (2002), studying wheat and corn, developed spectral indices using only the visible region of the spectrum to estimate vegetation fraction (VF). They found these indices to be more sensitive than NDVI to changes in vegetation fraction at high levels $(>60 \%)$ of cover, and the error in VF prediction did not exceed $10 \%$.

\section{Chlorophyll Content}

One very important and useful indicator of vegetation condition is the content of chlorophyll, a pigment producing the characteristic green color in plants. Variability in chlorophyll content is related to growth stage in the plant's life cycle, photosynthetic capacity/productivity, and stresses (Ustin et al. 1998). The measurement of chlorophyll content is also important with regard to nitrogen management, a key element of variable rate field fertilization technology.

Gitelson et al. (2005) developed a model, based upon field measurements made by means of a hyperspectral radiometer, for non-destructive estimation of chlorophyll in maize and soybean canopies. Separate models were developed for corn and soybeans individually, but the optimum model for evaluating corn and soybeans together, in an effort to obtain a non-species-specific solution, took the form $\left[\left(R_{\text {NIR/ }} R_{720-730}\right)-1\right]$ where $R$ is the reflectance at the specified wavelength in $\mathrm{nm}$. This model allowed estimation $(R$ $2=0.95$ ) of cholorophyll in the range $0.03-4.33 \mathrm{~g} / \mathrm{m}^{2}$, with an RMSE of less than 0.32 $\mathrm{g} / \mathrm{m}^{2}$ for corn and soybeans considered together.

Numerous other authors have dealt with the issue of remote sensing of chlorophyll content, including Broge and Leblanc (2000), Daughtry et al. (2000), and Broge and Mortensen (2002).

\section{Green Leaf Area Index}

The measurement of Leaf Area Index (LAI) is not only important as an estimate of primary production, but also as an input to climate models. Therefore, remote sensing of LAI is often undertaken. Gitelson et al. (2003b) proposed a technique to estimate LAI and green leaf biomass using spectral reflectance either in the green region (around 550 $\mathrm{nm}$ ) or at the red edge (near $700 \mathrm{~nm}$ ) along with the near-infrared (beyond $750 \mathrm{~nm}$ ). Close relationships were found between the spectral indices tested and LAI (ranging 
from 0 to more than 6) as well as green leaf biomass (ranging from 0 to $3500 \mathrm{~kg} / \mathrm{ha}$ ). Numerous other authors have addressed the topic of remote sensing of LAI including Gilabert et al. (1996), Carlson and Ripley (1997), Broge and Leblanc (2000), and Haboudane et al. (2004).

\section{Other Measurable Biophysical Variables}

Other biophysical variables may also be measurable by means of remote sensing. Danson et al. (1992) showed that the first derivatives of reflectance associated with the slopes of the lines near water-absorption bands were highly correlated with leaf water content. Gitelson et al. (2003a) developed a technique based upon remote sensing that accounted for more than 90 percent of the variability in mid-day canopy photosynthesis of irrigated corn. Researchers have also addressed crop yield (e.g., Hatfield 1983, Serrano et al. 2000, Shanahan et al. 2001, Teal et al. 2006), canopy transpiration (e.g., Inoue and Moran 1997), plant litter (e.g., Nagler et al. 2000, Streck et al. 2002); and phytomass (e.g., Daughtry et al. 1992).

\section{THE CHALLENGE: PRACTICAL APPLICATION OF BIOPHYSICAL MEASURES}

Using remote sensing, it is possible to infer certain biophysical parameters of cropland vegetation, but in order to make use of the biophysical properties in a practical manner, one must attempt to link them to a set of 'agronomic indicators.' This may mean developing algorithms that incorporate both spectral and agronomic parameters to provide economically viable, practical products (e.g., maps of pigment densities in specific fields, useful descriptors of general crop status and condition as depicted in map form, nutrient management information that can be used effectively and efficiently to improve the application of nitrogen, and biomass measurements used to estimate potential yield in near-real time). It is only through the development of such practical products that remote sensing will gain wide acceptance and use.

Precision farming is an emerging methodology designed to link management actions to site-specific soil and crop conditions, and place inputs of fertilizers, herbicides, and pesticides where they are most needed to maximize farm efficiency and minimize environmental contamination. One of the crucial parts in this system is information on soil and crop conditions at the temporal frequency and spatial resolution required for 
making crop management decisions. Remote sensing is a viable tool for providing such information.

\section{Crop water management}

Information on crop-water demand, water use, soil moisture condition, and related plant growth at different stages of cultivation can be obtained through use of various forms of remote sensing, extending from synoptic views using satellite data to detailed analyses with thermal and hyperspectral sensor systems. Bandara (2003), for example, used NOAA satellite data to assess the performance of three large irrigation projects in Sri Lanka. Within this analysis, estimates using remote sensing of crop-water utilization were compared to actual water availability to determine irrigation efficiency. In a related study, Martin De Santa Olalla et al. (2003) used GIS with NDVI and a hydrological management unit (HMU) to create an Irrigation Advisory Service linked to water requirements of crops and estimates of the volume of irrigation water used. Linking such approaches to groundwater use has further extended analysis methodologies. Wu et al. (1999), used Landsat Thematic Mapper data to characterize the relationship between land use and groundwater depletion in the fragile U.S. High Plains resource system.

Remote sensing has also been used to evaluate irrigation water distribution at variable scales of the agro-water system. Nellis (1985) used thermal infrared imagery, for example, at the field level to determine parameters related to uniformity of water distribution and conveyance system irregularities in Oregon. In western Turkey, research by Droogers and Kite (2002) used a parametric basin-scale model and a physically based crop-scale model linked to NOAA-AVHRR images to analyze water use for irrigation at the field scale, irrigation scheme scale, and basin scale.

Since early on in digital remote sensing, researchers have used various approaches to estimate crop evapotranspiration, soil moisture, and biomass growth (Bastiaanssen et al. 2001, Ray and Dadhwal 2001). Neale and colleagues (2005) provide an historical perspective on high resolution airborne remote sensing of crop coefficients for obtaining actual crop evapotranspiration. Although most approaches use simple direct correlations between remote sensed digital data and evapotranspiration, some combine various forms of remotely sensed data types. Consoli and colleagues (2006), for example, used IKONOS high resolution satellite along with hyperspectral ground data with agro-meteorological information from orange groves in southern Italy to estimate evapotranspiration fluxes.

Water impact on erosive capacity and sediment yield using GIS and remote sensing has also gained considerable attention by researchers. Khan et al. (2001), for example, used 
spatial data on land-forms, land cover, and slope to estimate potential erosivity and sediment yield in India. In addition, Wu and colleagues (1997) used spatial data linked to a GIS coupled with Landsat TM land cover data to evaluate USDA Conservation Reserve Program (CRP) lands and related soil properties in the U.S. High Plains.

Clearly remote sensing is playing an ever increasing role in water management of the agricultural system. Such developments have been further enhanced with the evolution of hyperspectral sensors and the ability to link spatially analyzed remote sensing data with other spatial data through GIS and GPS technologies.

\section{Crop and soil characteristics}

As has been articulated by Sullivan et al. (2005), numerous studies have demonstrated the utility of remote sensing for distinguishing various soil properties, including erosion prediction, application of agrochemicals to soils for precision management, soil organic carbon, iron oxide content, and soil texture (see also Chapter 24 on soils applications (Campbell, in this volume)). Over 25 years ago, Stoner and Baumgardner's work (1981), for example, showed an increasing level soil carbon was inversely correlated with reflectance in the visible and infrared regions. In contrast, more recent work by Bajwa and Tian (2005) demonstrated the potential of aerial visible/infrared (VIR) hyper-spectral imagery for characterizing soil fertility factors in the U.S. Midwest. Soil fertility parameters included $\mathrm{pH}$, organic matter $(\mathrm{OM}), \mathrm{Ca}, \mathrm{Mg}, \mathrm{P}, \mathrm{K}$, and soil electrical conductivity. In this analysis, the measured soil fertility characteristics were modeled on first derivatives of the reflectance data using partial least square regression. The model explained a higher degree of variability in $\mathrm{Ca}(82 \%), \mathrm{Mg}(72 \%)$, and $\mathrm{OM}$ $(66 \%)$, for example, and less so for properties such as $\mathrm{pH}(48 \%)$.

Controlled field and laboratory studies have been the basis in remote sensing research related to soil particle size. Such work has often relied on high spectral resolution radiometers (Salisbury and D'Aria 1992, for example). This research has found increasing spectral response with increasing sand content, which is likely associated with a corresponding decrease in water holding capacity of coarser soils.

The refinement in thermal sensing systems and access to hyperspectral sensors (as was earlier noted) have further extended remote sensing applications to soil properties. Salisbury and D'Aria (1992) have used thermal infrared band ratios to estimate quartz content, but varying levels of clay, iron, and soil organic carbon complicated the results.

According to Sullivan et al. (2005), Barnes and Baker (2000), and Russell (2003), spatially and temporally dynamic surface conditions, such as water content, surface roughness, crusting, and crop residue cover, significantly impact spectral response and complicate 
the remote sensing analysis process. For example, recent studies by Ben-Dor et al. (2003) and Eshel et al. (2004) have shown that crusted soil surfaces of many different types of soils tend to have higher reflective responses due to the simple occurrence of greater quartz exposures when such crusted soils are freshly tilled exposing quartz surfaces.

Ground based sensors or 'on the go' sensors (sensors mounted on a tractor and data mapped with coincident position information) have developed rapidly in recent years. Such efforts provide soil organic matter, electrical conductivity, nitrate content, and compaction (Barnes et al. 2003), and when integrated with other data sources maximize the information for the farm manager.

Numerous remote sensing studies of soil moisture (in addition to earlier references) have focused on the use of thermal and microwave sensing. Casanova et al. (2006) used microwave remote sensing models to improve estimates of soil moisture, and Verstraeten et al. (2006) used a combination of optical and thermal spectral information of METEOSAT imaging to determine thermal inertia relative to soil moisture content.

Also at the interface between water and soil dynamics are processes that lead to soil salinity in irrigated agricultural areas. Again remote sensing has provided important analysis of such applications, as illustrated by the work of Masoud and Koike (2006), in which they used Landsat TM/ETM taken over 16 years coupled with $30 \mathrm{~m}$ DEM and field observations in Egypt to successfully document salinity changes in soils and their related land cover.

With increasingly narrower hyperspectral bands in the thermal range of electromagnetic energy and coupled with other spatial data derived from field observations, remote sensing is clearly playing an ever more important role in understanding crop soil characteristics. Such efforts, when linked to GPS, provide promising results in precision agriculture.

\section{Precision Agriculture and 'on-the-go sensors'}

\section{Precision Agriculture}

Precision farming is an emerging methodology designed to link management actions to site-specific soil and crop conditions, and place inputs of fertilizers, herbicides, and pesticides where they are most needed to maximize farm efficiency and minimize environmental contamination. The core technologies in precision agriculture are GIS, GPS, and remote sensing. The importance of these technologies in agriculture was 
underscored when NASA (Stennis Space Center), in the early portion of the current century, embarked upon the Ag 2020 program in an effort to commercialize the geospatial technologies, develop practical tools for producers, and undertake projects with various types of crops to illustrate the utility of the technologies.

Critical to precision farming is the acquisition of information on soil and crop conditions at the temporal frequency and spatial resolution required for making crop management decisions. Remote sensing is no doubt a viable tool for providing such information. However, for remote sensing to contribute to the management of small parcels, the imagery must be of high spatial resolution. Until relatively recently, such satellite imagery has been unavailable, and though available today, it remains quite expensive. Examples of previous precision agriculture work done using data acquired by high-resolution satellite sensors include that of Yanget al. (2006) and Bannariet al. (2006). General summaries regarding procedures and issues related to precision agriculture are provided by Barnes et al. (1996), Bramley et al. (1999), Campanella (2000), and Moran (2000).

\section{The Role of Remote Sensing in Precision Agriculture}

While 'geospatial technologies,' especially GPS and GIS, are certainly visible, integral components of the movement in agriculture toward precision approaches, remote sensing unfortunately remains poorly understood and less widely used. Today, most combines are equipped with GPS capability, and even planting is often done within a framework of precise geographic location. Similarly, the concept of yield mapping and comparing those results to detailed soils maps have brought GIS to the fore in modern agriculture. Remote sensing, on the other hand, while it has much to offer the agriculturalist, seems less important to producers for several reasons including the high cost of obtaining imagery, the need to register the images to other spatial data, the need for imagery of both high spatial and temporal resolutions, and a learning curve that is rather steep for most on-farm operators and even agronomic consultants. The digital overlay and analysis of spatial, and especially spectral, datasets is perceived as being too difficult for many producers and consultants, and they often are reluctant to acquire the software skills necessary to accomplish the tasks noted previously. The need of most agricultural producers and consultants seems to be useful map products. Another challenge in applying remote sensing to agriculture in general has been the delivery of image data in a timely manner. Pelzmann (1997) indicates that imagery should be delivered within 48 hours of acquisition or less to be truly useful.

Despite the complexities associated with incorporating remote sensing into the day-today operations of farming, there are some relatively simple products that can serve to enhance the producer's understanding of his farm as well as facilitate site-specific 
management. Aerial photographs have potential for delineating management zones (Schepers et al. 2000). Conventional-color aerial photography, acquired at a leaf-off condition, is an important tool in the early stages of preparing a field for site-specific management. Such air photos provideanun commonly good view of general soil conditions; most specifically, the variability in organic content from place to place (Schepers 2002). Aerial videography has been shown to be a useful tool for monitoring within-field plant-growth variation, as well as establishing management zones for precision farming (Yang et al. 1998).

\section{Nitrogen Management}

One of the major environmental issues is the need for nitrogen $(\mathrm{N})$ management, as the ground water in some areas of intensive agriculture, such as the Midwestern U.S., has become increasingly polluted with nitrates. Because $\mathrm{N}$ is relatively cheap and small inputs increase yields, producers have a tendency to apply large amounts of 'insurance nitrogen,' thereby increasing the potential for groundwater pollution (Schepers 2002). Thus, there is a need to develop procedures, including possibly remote sensing, that may have utility for mitigating the problem of $\mathrm{N}$ overuse. The appropriate approach seems to be variable-rate technology in order to apply the fertilizer only on plants that are in need and only in portions of the field where that need exists, rather than across the entire field. Studies by Blackmer et al. (1996), Shanahan et al. (2001), and Scharf et al. (2002) provide useful background on the subject of nitrogen management by means of remote sensing.

\section{On-the-go sensors}

On-the-go-sensors include implement mounted devices that make measurements of soils, crop canopies, or even individual plants at close-range. The measurements may not necessarily be spectral in nature, but certainly could be.

The essence of the new approaches in site-specific management is highlighted by the fact that combine-mounted yield monitors are commonly used for attempting to assess within-field variation and to delineate crop-management zones (Pinter et. al. 2003). Yet, as Pinter et. al point out, yield maps may not be an accurate portrayal of the extremes of variability, and they do not provide information about yield-reducing stresses because they are acquired at the end of the season. Also, the yield maps only document the spatial distribution; they do not explain the cause of variation (Doerge 1999). This is where remote sensing is capable of making a contribution, but again, high spatial resolution is a requirement. 
Systems have been devised for closed-loop, real-time, variable-rate application implements (Adamchuk et al. 2003), including for identifying weeds versus soil or crop residue (e.g., Meyer et al. 1998). Often, the system involves a sprayer, for example to apply herbicide to weeds, which is operated by means of a computer linked to an optical sensor. The sensor provides a computer algorithm with an image of a weed, the analysis proceeds based either on leaf reflectance or leaf shape, and the algorithm makes the decision to activate the spray, thus (hopefully) killing the weed (Schepers 2002). A similar approach could be used to apply nitrogen to plants where leaf color or reflectance indicates a shortage of that particular nutrient. Again, the benefit is that an entire field is spared from large amounts of fertilizer or pesticides and only the plants in need actually receive the spray. Stamatiadis et al. (2006) used on-the-go multispectral sensing at close-range in a Greek vineyard to demonstrate the value of proximal sensing for optimizing production, improving wine quality, and reducing chemical inputs. Ground-based sensors are also used for monitoring soils. Such instruments provide soil organic matter, electrical conductivity, nitrate content, and compaction (Barnes et al. 2003), and when integrated with other data sources maximize the information for the farm manager.

\section{Specialty crops}

Viticulture, the cultivation of grapevines, generally for wine production, is an important agricultural and economic enterprise in many parts of the world, including the United States. Managers of large vineyards know that the extent of grapevine productivity is the result of many topographic, climatic, and edaphic parameters, and the assumption is that these parameters are spatially variable, thus causing differences in vine vigor and yield from place to place in the vineyard. Viticulturalists must monitor vineyard conditions for the purpose of making decisions about irrigation, fertilizer application, canopy management, and when to actually harvest the grapes in order to maximize juice (and thus wine) quality. An additional important objective of ongoing vineyard scrutiny is to detect the presence of stressors including pathogens that affect either the vegetation or the fruit itself. Therefore, remote sensing may be a cost effective tool for providing the viticulturalist with a synoptic view of the vineyard that yields useful practical information.

Several authors have conducted research on the subject of remote sensing of grapevines. General overviews of such work are provided by Lang (1997), Peterson and Johnson (2000), Carothers (2000), and Hall et al. (2002). Examples of 'viticultural sensing' include that by Johnson et al. (2001) who evaluated airborne multispectral imagery for delineating vineyard management zones as a step toward 'precision viticulture' while Lanjeri et al. (2004) used Landsat Thematic Mapper (TM) images and NDVI to assess change over time in Spanish vineyards. 
A few investigators have used remote sensing technologies to detect and/or monitor pathogens. Wildman et al. (1983) made use of color infrared aerial photography for detecting and monitoring the spread of Phyloxera, a root louse that can devastate entire grape-growing regions. Johnson et al. (1996) examined airborne CASI multispectral imagery at $5 \mathrm{~m}$ spatial resolution for the same purpose.

Work dealing with remote sensing as a means of inferring biophysical characteristics of grapevine canopies includes that of Montero et al. (1999) who used Landsat-TM data and NDVI to measure percent vegetation cover, biomass, plant height, and leaf area index. The authors found positive linear relationships with parameters measured in-situ in Spanish vineyards. Lanjeri et al. (2001) also used TM imagery acquired over vineyards in Central Spain to document high positive correlations between NDVI and biomass, plant height, and vegetation cover. Johnson et al. (2003) used IKONOS imagery to convert NDVI to LAI for two commercial vineyards in California, and estimated LAI with an $r^{2}$ of 0.72 when compared to in-situ measurements. Those authors concluded that remote sensing appears useful for mapping vineyard leaf area in low LAI vineyards. Stamatiadis et al. (2006) made use of ground-based canopy multispectral sensors to estimate biomass production and the quality of Merlot grapes in Northern Greece.

A review of the literature dealing with remote sensing in viticulture leads one to conclude that this application is indeed feasible but that there are also some unique constraints. First, imagery of high spatial resolution, on the order of a few meters, is required in order to make inferences about planted blocks of vines or even individual plants within those blocks (e.g., Hall et al. 2001). Distance between vine rows (often only a meter in California) will, of course, affect the outcome of image analyses. Temporal resolution is important as it relates to the important phenological stages in vine development (e.g., bud break, flowering, veraison, and harvest). Bramley et al. (2003) suggest that veraison $+/-$ two weeks is the optimal time for image acquisition (assuming that imagery is obtained at only one point in time). It seems as though little research has been conducted with hyperspectral sensors, but the previous literature indicates that broad-band sensors are capable of providing useful information. The target background for the sensor imaging rows of grapes (e.g., whether that background is green grass or bare soil) is an important consideration as is the fact that sensor fields of view in vineyards include wood posts and trellis wire, all of which combine to make the search for spectral end-members interesting if not downright difficult. 


\section{CHALLENGES AND THE FUTURE}

Since the early 1970s, one of the greatest challenges to using satellite remotely sensed data for agricultural applications has been the lack of usable images collected often enough and at consistent intervals over the growing season. This inadequate temporal resolution of nadir-viewing moderate and high spatial resolution satellite acquired imagery can only be resolved by increasing the revisit frequency of the sensors, and this can only be achieved by increasing the number of satellite sensors collecting imagery. Currently, and in the past, the revisit frequency of the moderate resolution sensors like Landsat and SPOT is or has been approximately bimonthly to monthly. Such temporal resolution is inadequate to capture key changing crop conditions (phenological stages) throughout the growing season. This is especially true in areas where there is frequent cloud cover. In the central US, for example, there is often only two or three usable images acquired during the growing season, and due to varying cloud cover conditions, the acquisition dates can significantly vary annually making year-to year comparisons of vegetation conditions very challenging and often impossible.

RapidEye is planning to launch a constellation of five satellites in 2008 with the objective of providing daily geospatial information of high spatial resolution to global customers with an interest in agriculture and forestry, among others (RapidEye 2007). The sensor is to be a five-channel multispectral system operating in the visible and nearinfrared. Such an operational capability would no doubt be of great interest to agriculturalists. Without such operational satellite remote sensing system the development of commercial remote sensing products to support agribusiness and the land management decision-making processes would be greatly hampered. Not having an operational system has created a lack of confidence in future availability and consistency in data types and its quality. Insufficient image temporal resolution and the lack of a dependable and consistent remote sensing system are the two most significant factors influencing the use of remotely sensed data in the area of agriculture.

During the early stages of the satellite remote sensing era, most research focused on the use of the data for classification of land cover types with crop types being a major focus among those interested in agricultural applications. Over the past decade or so, the work in agricultural remote sensing has focused more on characterization of plant biophysical properties. As scientists have gained greater access to spectroradiometer data and airborne and space borne hyperspectral data and imagery, a new area of research interest is focusing on the use of near infrared analysis and chemometrics software and models for characterizing the chemical constituencies of plant parts, soils, rocks, etc. Unfortunately, research findings in this area of study will not become operational until high quality hyperspectral satellite imagery become available at an affordable price. 
Efforts in the field of precision agricultural are leading to new commercial applications as studies continue to refine the science and instruments used in 'on-the-go' (implement-mounted) sensors. Special interest is now focusing on rapid in-the-field plant leaf nitrogen characterization so that real-time fertilizer applications can be implemented. Similar efforts are being made for other critical nutrients as well. In addition, researchers continue to develop agricultural applications that involve the use of high spatial resolution airborne imagery for field level 'prescription' of fertilizers and herbicides that are administered using 'smart' sprayer applicator technology. Airborne imagery is also being used to defining soil and crop management zones and hyperspectral measurements of plant conditions are being used as an indicator of soil nutrients conditions.

Spectral measurements are also being used to measure plant biophysical properties that can be linked to biogeochemical fluxes, with special interests in $\mathrm{CO}_{2}$. Remotely sensed data are also being used to map not only land cover, but land use, which has significant influence of $\mathrm{CO}_{2}$ fluxes. Such data will be very useful for assessing land use practices that influence land owner carbon credit qualifications.

Finally, remote sensing in agriculture is moving toward nano-scale analysis. A new and nontraditional remote sensing application involves the implanting of nano-chips in plant and seed tissue that can be used in near-real time to monitor crop. Clearly, these and other new approaches will reinforce the importance of remote sensing in future analysis of agricultural sciences.

\section{REFERENCES}

Adamchuk, V. , R. Perk, and J. Schepers, 2003. Applications of remote sensing in site551 specific management. University of Nebraska Cooperative Extension EC03-702.

Badhwar, G. D. and K. E. Henderson Estimating Development stages of corn from spectral data - an initial model. Agronomy Journal vol. 73 pp. 748-755. 1981.

Bajwa, S. G. and L. F. Tian Soil fertility characterization in agricultural fields using hyperspectral remote sensing. Transactions of the ASAE vol. 48 no. (6) pp. 2399-2406. 2005.

Bandara, K. M. P. S Monitoring irrigation performance in Sri Lanka with high560 frequency satellite measurements during the dry season. Agricultural Water Management vol. 58 no. (2) pp. 159170. 2003.

Bannari, A. , Pacheco , K. Staenz , H. McNairn , and K. Omari Estimating and mapping crop residues cover on agricultural lands using hyperspectral and IKONOS data. Remote Sensing of Environment vol. 104 pp. 447-459. 2006. 
Barnes, E. M. and M. G. Baker Multispectral data for mapping soil texture: possibilities and limitations. American Society of Agricultural Engineers vol. 16 pp. 731-741. 2000.

Barnes, E. , M. Moran , P. Pinter, and T. Clarke, 1996. Mulltispectral remote sensing and sitespecific agriculture: examples of current technology and future possibilities. Proceedings, 3rd International Conference on Precision Agriculture, pp. 843-854.

Barnes, E. M. , K. A. Sudduth , J. W. Hummel , S. M. Lesch , D. L. Corwin , C. Yang , C. S. T. Daughtry, and W. C. Bausch Remote-and ground-based sensor techniques to map soil properties. Photogrammetric Engineering and Remote Sensing vol. 69 no. (6) pp. 619-630. 2003.

Bastiaanssen, W. G. M. , R. A. L. Brito , M. G. Bos , R. A. Souza , E. B. Cavalcanti , and M. M. Bakker Low cost satellite data for monthly irrigation performance monitoring: benchmarks from Nilo Coelho, Brazil. Irrigation and Drainage Systems vol. 15 no. (1) pp. 53-79. 2001.

Bauer, M. E. Spectral inputs to crop identification and condition assessment. Proc. IEEE vol. 73 pp. 1071-1085. 1985.

Ben-Dor, E. , N. Goldshleger, Y. Benyamini , M. Agassi , and D. G. Blumberg The spectral reflectance properties of soil structural crusts in the 1.2- to 2.5-micrometer spectral region. Soil Science Society of America Journal vol. 67 pp. 289-299. 2003.

Blackmer, T. , J. Schepers , G. Varvel, and E. Walter-Shea Nitrogen deficiency detection using reflected shortwave radiation from irrigated corn canopies. Agronomy Journal vol. 88 pp. 1-5. 1996.

Bramley, R. , S. Cook, M. Adams, and R. Corner , 1999. How precision agriculture can help. A Report of the CSIRO Land and Water Division, pp. 30 pp.

Bramley, R. , B. Pearse , and P. Chamberlain , 2003. Being profitable precisely - a case study of precision viticulture from Margaret River. The Australian and New Zealand Grape-grower and Winemaker Annual Technical Issue, pp. 84-87.

Breshears, D. D. , N. S. Cobb , P. M. Rich , K. Price , C. D. Allen , R. G. Balice , W. H. Romme , J. H. Kastens , M. L. Floyd, J. Belnap , J. J. Anderson, O. B. Myers, and C.W. Meyer Regional vegetation die-off in response to global change type drought. Proceedings of the National Academy of Science vol. 102 no. (42) pp. 15144-15148. 2005.

Broge, N. and E. Leblanc Comparing prediction power and stability of broadband and hyperspectral vegetation indices for estimation of green leaf area index and canopy chlorophyll density. Remote Sensing of Environment vol. 76 pp. 156-172. 2000.

Broge, N. and J. Mortensen Deriving green crop area index and canopy chlorophyll density of winter wheat from spectral reflectance data. Remote Sensing of Environment vol. 81 no. (1) pp. 45-57. 2002.

Campanella, R. Testing components toward a remote-sensing-based decision support system for cotton production. Photogrammetric Engineering and Remote Sensing vol. 66 no. (10) pp. 1219-1227. 2000.

Campbell, J. , in this volume. Remote Sensing of Soils. Chapter 24.

Carlson, T. and D. Ripley On the relation between NDVI, fractional vegetation cover, and leaf area index. Remote Sensing of Environment vol. 62 no. (3) pp. 241-252. 1997. 
Carothers, J. Imagery technology meets vineyard management. Practical Winery and Vineyard vol. 21 no. (1) pp. 54-62. 2000.

Casanova, J. J. , J. Judge, and J. W. Jones Calibration of the CERES-Maize model for linkage with a microwave remote sensing model. Transactions of the American Society of Agricultural and Biological Engineers vol. 49 no. (3) pp. 783-792. 2006.

Chen, C. and H. Mcnairn A neural network integrated approach for rice crop monitoring. International Journal of Remote Sensing vol. 27 no. (7) pp. 1367-1393. 2006.

Consoli, S. , G. D'Urso, and A. Toscano Remote sensing to estimate ET-fluxes and the performance of an irrigation district in southern Italy. Agricultural Water Management vol. 81 no. (3) pp. 295314. 2006.

Danson, F. , M. Steven , T. Malthus, and J. Clark High-spectral resolution data for determining leaf water content. International Journal of Remote Sensing vol. 13 pp. 461-470. 1992.

Daughtry, C. , K. Gallo , S. Goward , S. Prince , and W. Kustas Spectral estimates of absorbed radiation and phy-tomass production in corn and soybean canopies. Remote Sensing of Environment vol. 39 pp. 141-152. 1992.

Daughtry, C. , C. Walthall , M. Kim , E. deColstoun , and J. McMurtrey Estimating corn leaf chlorophyll concentration from leaf and canopy reflectance. Remote Sensing of Environment vol. 74 pp. 229-239. 2000.

Doerge, T. Site specific agriculture: yield map interpretation. Journal of Production Agriculture vol. 12 no. (1) pp. 54-61. 1999.

Doraiswamy, P. C. , S. Moulin , P. W. Cook, and A. Stern Crop yield assessment from remote sensing. Photogrammetric Engineering and Remote Sensing vol. 69 no. (6) pp. 665-674. 2003.

Droogers, P. and G. Kite Remotely sensed data used for modeling at different hydrological scales. Hydrological Processes vol. 16 no. (8) pp. 1543-1556. 2002.

Eshel, G. G. , J. Levy, and M. J. Singer Spectral reflectance properties of crusted soils under solar illumination. Soil Science Society of America Journal vol. 68 pp. 1982-1991. 2004.

Estes, J. and J. Jensen, 1998. Development of remote sensing digital image processing systems and raster GIS. In T. Forsman (ed.) The History of Geographic Information Systems, Longman, New York, pp. pp. 163-180.

Ferencz, C. S. , P. Bognar , J. Lichtenberger , D. Hamar , G. Y. Tarcsai , G. Timar , G. Molnar , S. Z. Pasztor , P. Steinbach, B. Szekely , O. E. Ferencz, and I. Ferencz-Arkos Crop yield estimation by satellite remote sensing. International Journal of Remote Sensing vol. 25 no. (20) pp. 4113-4149. 2004.

Gilabert, M. , S. Gandia, and J. Melia Analyses of spectral-biophysical relationships for a corn canopy. Remote Sensing of Environment vol. 55 no. (1) pp. 11-20. 1996.

Gitelson, A. , Y. Kaufman, R. Stark, and D. Rundquist Novel algorithms for remote estimation of vegetation fraction. Remote Sensing of Environment vol. 80 pp. 76-87. 2002.

Gitelson, A. , S. Verma , A. Vina , D. Rundquist, G. Keydan , B. Leavitt, T. Arkebauer , G. Burba , and A. Suyker Novel technique for remote estimation of $\mathrm{CO}_{2}$ flux in maize. Geophysical Research Letters vol. 30 no. (9) pp. 1486 doi:10,1029/2002GL016543. 2003a. 
Gitelson, A. , A. Vina , T. Arkebauer , D. Rundquist, G. Keydan, and B. Leavitt Remote estimation of leaf area index and green leaf biomass in maize canopies. Geophysical Research Letters vol. 30 no. (5) 1148, doi:10,1029/2002GL016450. 2003b.

Gitelson, A. , A. Vina , V. Ciganda , D. Rundquist, and T. Arkebauer Remote estimation of canopy chlorophyll content in crops. Geophysical Research Letters vol. 32 pp. L08403 doi:10.1029/2005GL022688,2005. 2005.

Goel, P. K. , S. O. Prasher , J. A. Landry, R. M. Patel , A. A. Viau, and J. R. Miller Estimation of crop biophysical parameters through airborne and field hyperspectral remote sensing. Transactions of the American Society of Agricultural Engineers vol. 46 no. (4) pp. 1235-1246. 2003.

Goodman, M. A technique for the identification of farm crops on aerial photographs. Photogrammetric Engineering vol. 25 pp. 131-137. 1959.

Goward, S. N. , T. Arvidson, D. L. Williams, R. Irish, and J. Irons, in this volume. Moderate Spatial Resolution Optical Sensors. Chapter 9.

Groten, S. M. E. NDVI-crop monitoring and early yield assessment of Burkina Faso. International Journal of Remote Sensing vol. 14 no. (8) pp. 1495-1515. 1993.

Haboudane, D. , J. Miller , E. Pattey , P. Zarco-Tejada , and I. Strachan Hyperspectral vegetation indices and novel algorithms for predicting green LAI of crop canopies: modeling and validation in the context of precision agriculture. Remote Sensing of Environment vol. 90 pp. 337-352. 2004.

Hadria, R. , B. Duchenin , A. Lahrouni , S. Khabba , S. Er-Raki, G. Dedieu , A. G. Chehbouni , and A. Olioso Monitoring of irrigated wheat in a semi-arid climate using crop modeling and remote sensing data: impact of satellite revisit time frequency. International Journal of Remote Sensing vol. 27 no. (6) pp. 1093-1117. 2006.

Hall, A. J. , P. Louis and D. W. Lamb , 2001. A method for extracting detailed information from high resolution multispectral images of vineyards. Proceedings of the 6th International Conference on Geocomputation, ISBN 1864995637, University of Queensland, Brisbane.

Hall, A. , D. Lamb , B. Holzapfel, and J. Louis Optical remote sensing applications in viticulture - a review. Australian Journal of Grape and Wine Research vol. 8 no. (1) pp. 37-47. 2002.

Hatfield, J. Remote sensing estimators of potential and actual crop yield. Remote Sensing of Environment vol. 13 pp. 301-311. 1983.

Inoue, Y. and M. Moran A simplified method for remote sensing of daily canopy transpiration - a case study with direct measurements of canopy transpiration in soybean canopies. International Journal of Remote Sensing vol. 18 no. (1) pp. 139-152. 1997.

Jensen, J. R. , 2007. Remote Sensing of the Environment, An Earth Resource Perspective. 2nd Edn. Prentice-Hall, Upper Saddle River, NJ, pp. 544 pp.

Johnson, L. , B. Lobitz , R. Armstrong, R. Baldy , E. Weber , J. DeBendictis , and D. Bosch Airborne imaging aids vineyard canopy evaluation. California Agriculture vol. 50 no. (4) pp. 1418. 1996.

Johnson, L. , D. Bosch , D. Williams, and B. Lobitz Remote sensing of vineyard management zones: implications for wine quality. Applied Engineering in Agriculture vol. 17 no. (4) pp. 557-560. 2001. 
Johnson, L. , D. Roczen , S. Youkhana , R. Nemani, and D. Bosch Mapping vineyard leaf area with multispectral satellite imagery. Computers and Electronics in Agriculture vol. 38 pp. 33-44. 2003.

Justice, C. O. and C. J. Tucker, in this volume. Coarse Spatial Resolution Optical Sensors. Chapter 10.

Kastens, J. H. , T. L. Kastens , D. L. A. Kastens , K. P. Price , E. A. Martinko, and R. Lee Image masking for crop yield forecasting using time series AVHRR NDVI imagery. Remote Sensing of Environment vol. 99 no. (3) pp. 341-356. 2005.

Khan, M. A. , V. P. Gupta, and P. C. Moharana Watershed prioritization using remote sensing and geographical information system: a case study from Guhiya, India. Journal of Arid Environments vol. 49 no. (3) pp. 465-475. 2001.

Kogan, F. , B. Yang, W. Guo , Z. Pei , and X. Jiao Modelling corn production in China using AVHRR-based vegetation health indices. International Journal of Remote Sensing vol. 26 no. (11) pp. 2325-2336. 2005.

Landgrebe, D. , 1986. A brief history of the Laboratory for Applications of Remote Sensing (LARS) , http:/ / www.lars.purdue.edu/ home/ LARSHistory.html

Lang, L. Use of GIS, GPS, and remote sensing: spread to California's winegrowers. Modern Agriculture vol. 1 no. (2) pp. 12-16. 1997.

Lanjeri, S. , J. Melia, and D. Segarra A multitemporal masking classification for vineyard monitoring in Central Spain. International Journal of Remote Sensing vol. 22 no. (16) pp. 3167-3186. 2001.

Lanjeri, S. , D. Segarra, and J. Melia Interannual vineyard crop variability in the Castilla-LaMancha region during the period 1991-1996 with Landsat Thematic Mapper images. International Journal of Remote Sensing vol. 25 no. (12) pp. 2441-2457. 2004.

Lloyd, D. A phenological classification of terrestrial vegetation cover using shortwave vegetation index imagery. International Journal of Remote Sensing vol. 11 pp. 2269-2279. 1990.

Martin De Santa Olalla, F. , A. Calera, and A. Dominguez Monitoring irrigation water use by combining Irrigation Advisory Service, and remotely sensed data with a geographic information system. Agricultural Water Management vol. 61 no. (2) pp. 111-124. 2003.

Masoud, A. A. and K. Koike Arid land salinization detected by remotely-sensed landcover changes: acase study in the Siwa region, NW Egypt. Journal of Arid Environments vol. 66 no. (1) pp. 151167. 2006.

McMaster, G. S. , 2004. Simulating crop phenology. 4th International Crop Science Congress. Brisbane, Australia, September 27-October 1 2004. http:/ / www.cropscience.org.au/ icsc2004/ poster/ 2/ 8/607mcmaster.htm

Meyer, G. , T. Mehta, M. Kocher, D. Mortensen, and A. Samal Textural imaging and discriminate analysis for distinguishing weeds for spot spraying. Transactions of the ASAE vol. 41 no. (4) pp. 1189-1197. 1998.

Montero, F. , J. Melia , A. Brasa , D. Segarra , A. Cuesta , and S. Lanjeri Assessment of vine development according to available water resources by using remote sensing in LaMancha, Spain. Agricultural Water Management vol. 40 pp. 363-375. 1999. 
Moran, S. , 2000. Image-based remote sensing for agricultural management: perspectives of image providers, research scientists, and users. Proceedings of the Second International Conference on Geospatial Information in Agriculture and Forestry, I: 23-I, pp. 29.

Nagler, P. , C. Daughtry, and S. Goward Plant litter and soil reflectance. Remote Sensing of Environment vol. 71 pp. 207-215. 2000.

Neale, C. M. U. , H. Jayanthi, and J. L. Wright Irrigation water management using high resolution airborne remote sensing. Irrigation and Drainage Systems vol. 19 no. (3-4) pp. 321-336. 2005.

Nellis, M. D. Interpretation of thermal infrared imagery for irrigation water resource management. Journal of Geography vol. 84 no. (1) pp. 11-14. 1985.

Nellis, M. D. Remote sensing for monitoring water demand in Western Kansas. Papers and Proceedings of the Applied Geography Conferences vol. 9 pp. 56-62. 1986.

Nicholas, H. Using remote sensing to determine the date of a fungicide application on winter wheat. Crop Protection vol. 23 no. (9) pp. 853-863. 2004.

Pelzmann, R. Using imagery in field management. Modern Agriculture vol. 1 no. (2) pp. 17-19. 1997.

Peterson, D. and L. Johnson The application of Earth science findings to the practical problems of growing winegrapes. Geographic Information Sciences vol. 6 no. (2) pp. 181-187. 2000.

Pinter, P. , J. Hatfield , J. Schepers , E. Barnes , S. Moran , C. Daughtry, and D. Upchurch Remote sensing for crop management. Photogrammetric Engineering and Remote Sensing vol. 69 no. (6) pp. 647-664. 2003.

Pinter, P. , J. Ritchie, J. Hatfield, and G. Hart The Agricultural Research Service's remote sensing program: an example of interagency collaboration. Photogrametric Engineering and Remote Sensing vol. 69 no. (6) pp. 615-618. 2003.

Prasad, A. K. , L. Chai , R. P. Singh, and M. Kafatos Crop yield estimation model for Iowa using remote sensing and surface parameters. International Journal of Applied Earth Observation and Geoinformation vol. 8 no. (1) pp. 26-33. 2006.

Price, K. , S. Egbert, R Lee, R. Boyce, and M. D. Nellis Mapping land cover in a high plains agroecosystem using a multi-date landsat thematic mapper modeling approach. Transactions of the Kansas Academy of Science vol. 100 no. (1-2) pp. 21-33. 1997.

Quarmby, N. A. , M. Milnes , T. L. Hindle, and N. Silleos The use of multitemporal NDVI measurements from AVHRR data for crop yield estimation and prediction. International Journal of Remote Sensing vol. 14 no. (2) pp. 199-210. 1993.

RapidEye 2007. Welcome to RapidEye. http:/ / www.rapideye.de/(Last accessed January 12 2008).

Ray, S. S. and V. K. Dadhwal Estimation of crop evapotranspiration of irrigation command area using remote sensing and GIS. Agricultural Water Management vol. 49 no. (3) pp. 239-249. 2001.

Reed, B. C. , J. H. F. Brown, D. VanderZee, T. R. Loveland, J. W. Merchant, and D. O. Ohnlen Measuring phenological variability from satellite imagery. Journal of Vegetation Science vol. 5 pp. 703-714. 1994.

Reed, B. C. , T. R. Loveland, and L. L. Tieszen An approach for using AVHRR data to monitor U.S. Great Plains Grasslands. Geocarto International vol. 11 no. (3) pp. 13-22. 1996. 
Reeves, R. (ed.) 1975. Manual of Remote Sensing. Falls Church, Virginia: American Society of Photogrammetry.

Reyniers, M. and E. Vrindts Measuring wheat nitrogen status from space and ground-based platform. International Journal of Remote Sensing vol. 27 no. (3) pp. 549-567. 2006.

Rundquist, D. and S. Samson, 1983. Application of remote sensing in agricultural analysis. Chapter 15 in B. Richason, Jr., ed. , Introduction to Remote Sensing of the Environment. Kendall/Hunt Publishing Company, Dubuque, pp. pp. 317-337.

Russell, C. A. Sample preparation and prediction of soil organic matter properties by near-infrared reflectance spec-troscopy. Communications in Soil Science and Plant Analysis vol. 34 pp. 15571572. 2003.

Salisbury, J. W. and D. M. D'Aria Infrared (8-14 micrometers) remote sensing of soil particle size. Remote Sensing of Environment vol. 42 pp. 157-165. 1992.

Scharf, P. , J. Schmidt , N. Kitchen, K. Sudduth , S. Hong, J. Lory, and J. Davis Remote sensing for Nitrogen management. Journal of Soil and Water Conservation vol. 57 no. (6) pp. 518-524. 2002.

Schepers, A. , 2002. Comparison of GIS approaches that integrate soil and crop variables to delineate management zones for precision agriculture. Masters Thesis, Department of Geography, University of Nebraska-Lincoln, pp. 59 pp.

Schepers, J. , M. Schlemmer, and R. Ferguson Site-specific considerations for managing phosphorus. Journal of Environmental Quality vol. 29 pp. 125-130. 2000.

Seidl, M. S. , W. D. Batchelor, and J. O. Paz Integrating remotely sensed images with a soybean model to improve spatial yield simulation. Transactions of the American Soceity of Agricultural Engineers vol. 47 no. (6) pp. 2081-2090. 2004.

Serrano, L. , I. Filella, and J. Penuelas Remote sensing of biomass and yield of winter wheat under different Nitrogen supplies. Crop Science vol. 40 pp. 723-731. 2000.

Shanahan, J. , J. Schepers , D. Francis , G. Varvel , W. Wilhelm , J. Tringe , M. Schlemmer , and D. Major Use of remote-sensing imagery to estimate corn grain yield. Agronomy Journal vol. 93 pp. 583-589. 2001.

Stamatiadis, S. , D. Taskos , C. Tsadilas , C. Christofides , E. Tsadila , and J. Schepers Relation of ground-sensor canopy reflectance to biomass production and grape color in two Merlot vineyards. American Journal of Enology and Viticulture vol. 57 no. (4) pp. 415-422. 2006.

Steven, M. D. , P. V. Biscoe, and K. W. Jaggard Estimation of sugar beet productivity from reflection in the red and infrared spectral bands. International Journal of Remote Sensing vol. 4 pp. 325-334. 1983.

Stoner, E. R. and M. F. Baumgardner Characteristic variations in reflectance of surface soils. Soil Science Society of America Journal vol. 45 pp. 1161-1165. 1981.

Streck, N. , D. Rundquist, and J. Connot Estimating residual wheat dry matter from remote sensing measurements. Photogrammetric Engineering and Remote Sensing vol. 68 no. (11) pp. 1193-1201. 2002. 
Sullivan, D. G. , J. N. Shaw , D. Rickman, P. L. Mask, and J. C. Luvall Using remote sensing data to evaluate surface soil properties in Alabama ultisols. Soil Science vol. 170 no. (12) pp. 954-968. 2005.

Teal, R. , B. Tubana , K. Girma , K. Freeman , D. Arnall , O. Walsh, and W. Raun In season prediction of corn grain yield potential using normalized difference vegetation index. Agronomy Journal vol. 98 pp. 1488-1494. 2006.

Thenkabail, P. S. , E. A. Enclona, M. S. Ashton, and B. Van Der Meer Accuracy assessments of hyperspectral waveband performance for vegetation analysis applications. Remote Sensing of Environment vol. 91 no. (3-4) pp. 354-376. 2004.

Tieszen, L. L. , B. C. Reed, N. B. Bliss , B. K. Wylie, and D. D. Dejong NDVI C3 and C4 production and distributions in Great Plains Grassland cover classes. Ecological Applications vol. 7 no. (1) pp. 59-78. 1997.

Ustin, S. , M. Smith , S. Jacquemoud , M. Verstraete , and Y. Govaerts , 1998. GeoBotany: Vegetation mapping for Earth sciences, in A. Rencz (ed.), Manual of Remote Sensing, Volume 3 , John Wiley \& Sons, Hoboken, NJ, pp. pp. 189-248.

Verstraeten, W. W. , F. Veroustraete , C. J. Van Der Sande , I. Grootaers , and J. Feyen Soil moisture retrieval using thermal inertia, determined with visable and thermal space-borne data, validated for European forests. Remote Sensing of Environment vol. 101 no. (3) pp. 299-314. 2006.

Vijaya-Kumar, P. , Y. S. Ramakrishna , D. V. Bhaskara-Rao , G. Sridhar , G. Srinivasa-Rao , and G. G. S. N. Rao Use of remote sensing for drought stress monitoring, yield prediction and varietal evaluation in castor beans (Ricinus communis L.). International Journal of Remote Sensing vol. 26 no. (24) pp. 5525-5534. 2005.

Vina, A. , A. Gitelson, D. Rundquist, G. Keydan, B. Leavitt, and J. Schepers Monitoring maize (Zea mays L.) phenology with remote sensing. Agronomy Journal vol. 96 pp. 1139-1147. 2004.

Wang, J. , P. M. Rich , K. P. Price, and W. Dean-Kettle Relations between NDVI, grassland production, and crop yield in the central great plains. Geocarto International vol. 20 no. (3) pp. 511. 2005.

Wildman, W. , R. Nagaoka, and L. Lider Monitoring spread of grape Phlloxera by color infrared aerial photography and ground investigation. American Journal for Enology and Viticulture vol. 34 no. (2) pp. 83-94. 1983.

Wu, J. , M. Ranson, M. D. Nellis , K. Price, and S. Egbert Evaluating CRP land soil properties using remote sensing and GIS techniques. Journal of Soil and Water Conservation vol. 52 no. (5) pp. 352-358. 1997.

Wu, J. , M. Ransom, M. D. Nellis , H. Su , and B. Rundquist Characterizing the relationships between land use and groundwater for Finney County, Kansas. Geographical and Environmental Modeling vol. 3 no. (2) pp. 203-215. 1999.

Yang, C. , G. Anderson, and J. Everitt A view from above: characterizing plant growth with aerial videography. GPS World pp. April, 34-37 1998.

Yang, C. , J. H. Everitt , J. M. Bradford, and D. Murden Airborne hyperspectral imagery and yield monitor data for mapping cotton yield variability. Precision Agriculture vol. 5 no. (5) pp. 445-461. 2004. 
Yang, C. , J. H. Everitt, and J. M. Bradford Comparison of QuickBird satellite imagery and airborne imagery for mapping grain sorghum yield patterns. Precision Agriculture vol. 7 no. (1) pp. 33-44. 2006.

Ye, X. , K. Sakai , L. O. Garciano , S. I. Asada, and A. Sasao Estimation of citrus yield from airborne hyperspectral images using a neural network model. Ecological Modelling vol. 198 no. (3-4) pp. 426-432. 2006.

Yu, F. , K. P. Price , J. Ellis, and P. Shi Response of seasonal vegetation development to climatic variations in eastern central Asia. Remote Sensing Environment vol. 87 pp. 42-54. 2003.

Zhang, P. , B. Anderson, B. Tan , D. Huang, and R. Myneni Potential monitoring of crop production using a satellite-based Climate-Variability Impact Index. Agricultural and Forest Meteorology vol. 132 no. (3-4) pp. 344-358. 2005. 